\title{
Proceeding
}

11th World Congress of Performance Analysis of Sport, 16-18 November 2016. International Society of Performance Analysis of Sport. Alicante, Spain

\section{Analysis of the throwing speed in the different positions in the field during the competition}

\author{
JUAN CARLOS ZAPARDIEL CORTÉS ${ }^{1} \triangle$, HELENA VILA², JOSÉ ARTURO ABRALDES ${ }^{3}$, CARMEN \\ MANCHADO ${ }^{4}$, CARMEN FERRAGUT $^{1}$ \\ 1 University of Alcalá, Spain \\ 2University of Vigo, Spain \\ 3 University of Murcia, Spain \\ ${ }^{4}$ University of Alicante, Spain
}

\begin{abstract}
The studies that analyse the throwing speed in the different positions on the field in high-performance handball are scarce. These contributions are nonexistent if the analysis refers to the throwing speed during the competition. For this reason, the objective of this research was to analyse the throwing speed in the central positions during the matches at the 23rd Men's World Handball Championship. Three thousand two hundred and forty-two throws in the matches of this championship were analysed. The throwing positions tested were the left back, the centre back and the right back. A radar (StalkerPro S.A., Plano), with a frequency of $100 \mathrm{~Hz}$ and a sensitivity of $0.045 \mathrm{~m} / \mathrm{s} 1$, fixed on a tripod behind the goal, was used. Analysis was performed using SPSS software (version 22). The variables were analysed with the Mann-Whitney Utest. Statistically significant differences were not found among all the throws carried out by the participating teams in the championship. There are statistically significant differences in the throwing speed between the best 8 teams with respect to the other 8 teams of the championship in the central position in the first half of the match $(p>0,05)$, both for the total number of throws and the effectiveness (goal/not a goal). The best teams obtain higher throwing speed in the central position, but there is no difference in relation to
\end{abstract}

Corresponding author. University of Alcalá de Henares, Spain. http://orcid.org/0000-0002-1835-2085

E-mail: carlos.zapardiel@uah.es

11th World Congress of Performance Analysis of Sport, 16-18 November 2016. International Society of Performance Analysis of Sport. Alicante, Spain.

JOURNAL OF HUMAN SPORT \& EXERCISE ISSN 1988-5202

(c) Faculty of Education. University of Alicante

doi:10.14198/jhse.2017.12.Proc3.12

S882 | $2017 \mid$ Proc3 | VOLUME 12

C 2017 University of Alicante 
effectiveness. Players may increase the throwing speed in the central position due to the concentration of a higher number of players in that area. Key words: HANDBALL, VELOCITY, ACCURACY, SHOT.

\section{Cite this article as:}

Zapardiel Cortés, J.C., Vila, H., Abraldes, J.A., Manchado, C., \& Ferragut, C. (2017). Analysis of the throwing speed in the different positions in the field during the competition. Journal of Human Sport and Exercise, 12(3proc), S882-S891. doi:https://doi.org/10.14198/ihse.2017.12.Proc3.12 


\section{INTRODUCTION}

Throwing speed in handball has been widely studied in different research projects (Hermassi et al., 2015; Raeder et al., 2015; Serrien et al., 2016). Even though all the analysed works about throwing speed carried out the evaluations in training situations or in situations modified for the study (Aguilar-Martínez et al., 2012; Hermassi et al., 2015; Van den Tillaar \& Marques, 2011), none of them carried out the measurement in real competition situations. Among the cited studies, throwing speed in handball players in relation to the anthropometric variables has been studied (Debanne \& Laffaye, 2011; Vila et al., 2009), also in relation to biomechanical studies (Van den Tillaar et al., 2013; Wagner et al., 2014; Wagner et al., 2010; Wagner et al., 2011) to physical capacities (Granados et al., 2013; Sabido et al., 2016; Van den Tillaar, 2004) and to the degree of opposition during the throw (Rivilla et al., 2010a; Rivilla et al., 2010b).

Among the aforementioned studies, there are researchers who analyse the throwing accuracy and others who state that reaching maximum speed during a throw in handball does not always result in greater efficacy. Even up to certain submaximal speeds, throwing speed and accuracy are inversely proportional (García et al., 2013; Gorostiaga et al., 1999; Van den Tillaar, 2003; Van den Tillaar \& Ettema, 2003; Wagner et al., 2011). The handball throw is an action that requires, among other factors, accuracy and speed in order to be effective (Gómez et al., 2011). Efficacy is the last purpose of each throw, it would be preferable to carry it out with submaximal velocity so we could save energy and reduce the potential risk of injury. Gómez Navarrete et al. (2011) develops a precision about efficacy and includes specific throw as one of the most important factors in the performance of the handball player.

According to Bárcenas \& Román (1991), the game lines in handball refer to organization and situation, both in static and in dynamic situations, of the attack and defence teams. In the attack phase, this situation normally seems to represent two lines: offensive first line, composed of the players located closer to the centre line (players A, B and C - Figure 1); and offensive second line, made up of the players near the goal area (players $D, E$ and $F-$ Figure 2). The specific position would be determined by the area of the playing court that marks the player's situation both in defence and in attack actions: A, B, C, D, E and F (Figure 1).

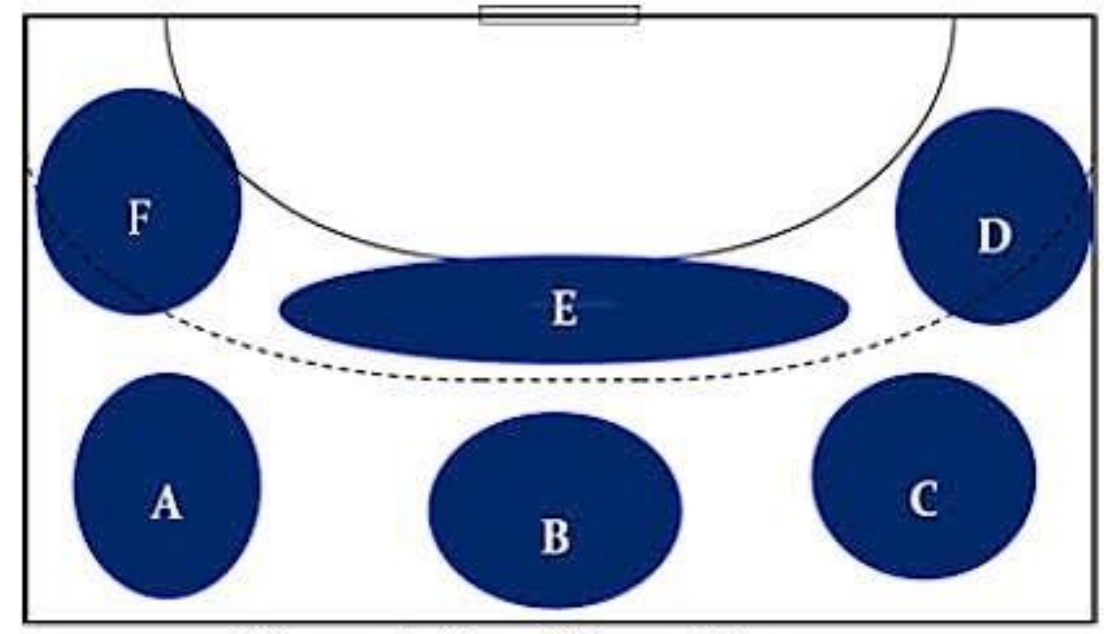

Figure 1. Specific positions 
The handball studies analysing throwing speed are scarce. Rivilla et al. (2011) checked the differences in speed among the different specific attacking positions by assessing the throw both with a medicine ball and with a handball ball. Zapartidis et al. (2009) assessed female handball players' throwing speed in all the game specific positions, including the goalkeeper's throws. Rogulj et al. (2005) identified the differences in basic motor skills, amongst them the medicine ball throw, in elite female handball players according to the game positions.

In order to study and analyse this, it is necessary to measure the throwing speed during the competition. This research aimed to analyse the throwing speed in the central positions during the matches at the 23rd Men's World Handball Championship.

\section{METHODS}

During the 2013 Men's World Handball Championship held in Spain, ball speed from 2265 throws out of the 3242 analysed ones were registered. To that effect, 47 out of the 76 matches played during the championship were observed: 31 during the group stage, 8 during the qualifying round of 16, 4 in the quarterfinals, and 4 in the semi-finals and final.

In situ, two qualified observers per match gathered twelve variables regarding throwing using an observation tool (Figure 1). These variables were: playing time, first or second half, player who carries out the throw, zone of the playing field from where the shot is performed, distance, type, trajectory, opposition, contact, effectiveness, accuracy, and attack phase. All the observers had brought the variables together and practiced data collection in the four weeks preceding the championship matches.

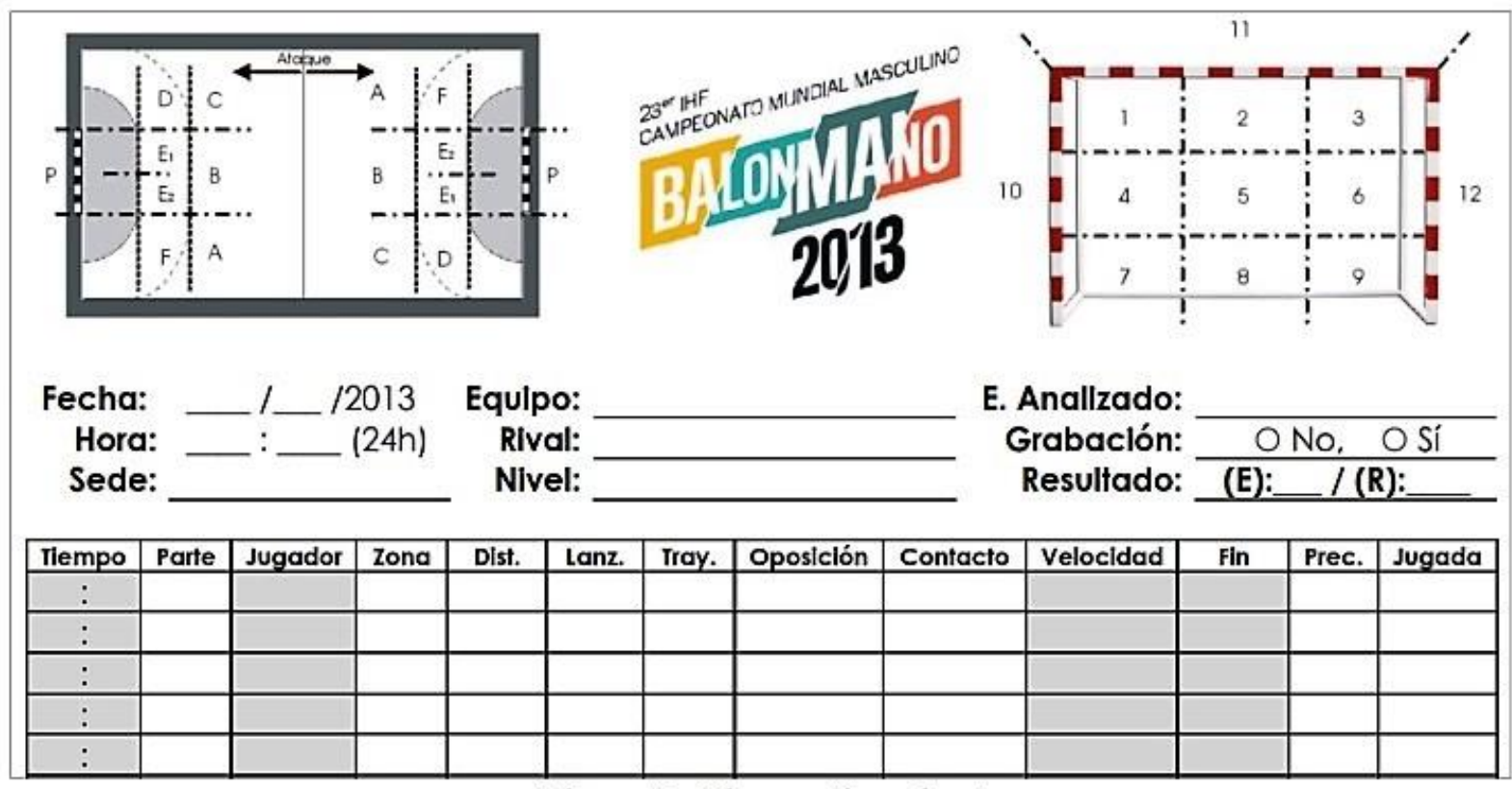

Figure 2. Observation sheet

At the same time, throwing velocity was assessed using a radar gun (StalkerPro Inc., Plano, TX, USA) with $100 \mathrm{~Hz}$ recording frequency and $0.045 \mathrm{~m} / \mathrm{sec}-1$ sensitivity, placed behind the goal post in a direction perpendicular to the player. The radar was placed behind the goal at a distance of 3 metres and a height of 
1.20 metres. Two observers carried out this task. One of them registered throwing speed; the other one registered the player who executed the throw.

Once the championship ended, the analysed matches were downloaded and they were viewed again in order to correct the possible mistakes that may have arisen while registering data in situ. LINCE software was used for the register of the observed actions (Gabín, 2011); it was developed by the research team of the Laboratori d'Observació de la Motricitat from INEF in Lleida. This software package is developed in Java, making it compatible with multiple platforms. It has been designed to observe any type of event and allows to carry out systems designs, video registers and data quality controls, and also to export results in different formats (Lozano, 2014). Another advantage of this software is the ease to create new register panels based on a basic register panel.

\section{Statistical analysis}

The reliability of the observation of the matches assessing the intraobserver concordance was studied using Cohen's Kappa index (Cohen, 1960). The interpretation of the agreement degree proposed by Landis y Koch (1977) was valued as very good.

The collected data were codified and registered on an Excel data entry form. Afterwards, the data were filtered.

Statistical analysis was carried out using SPSS software (version 22). A descriptive analysis of the variables speed, first or second half, and effectiveness of each of the teams analysed. The Kolgomorov-Smirnov test was used to check normality and homogeneity. The results show non-parametric variables. Subsequently, the differences between first 8 national teams and second 8 national teams from each position were analysed with the Mann-Whitney U-test. Throwing velocity from the first line by effectiveness were analysed with Kruskal-Wallis test. The $p \leq 0.05$ criterion was used for establishing statistical significance.

\section{RESULTS}

Table1. Mean and standard deviations values $(\bar{x} \pm s d$ ) corresponding to throwing velocity from the first line.

\begin{tabular}{|l|c|c|c|}
\hline & $\begin{array}{c}\text { Right side } \\
\left(\mathbf{m}^{*} \mathbf{s}^{-1}\right)\end{array}$ & $\begin{array}{c}\text { Centre } \\
\left(\mathbf{m}^{*} \mathbf{s}^{-1}\right)\end{array}$ & $\begin{array}{c}\text { Left side } \\
\left(\mathbf{m}^{*} \mathbf{s}^{-1}\right)\end{array}$ \\
\hline All throws & $\begin{array}{c}22,44 \pm 4,25^{*} \\
(\mathrm{n}=467)\end{array}$ & $\begin{array}{c}23,93 \pm 3,76 \\
(\mathrm{n}=1287)\end{array}$ & $\begin{array}{c}21,86 \pm 4,01^{*} \\
(\mathrm{n}=511)\end{array}$ \\
\hline Goal throw & $\begin{array}{c}22,79 \pm 4,20^{*} \\
(\mathrm{n}=229)\end{array}$ & $\begin{array}{c}24,04 \pm 3,56 \\
(\mathrm{n}=618)\end{array}$ & $\begin{array}{c}22,11 \pm 3,96^{*} \\
(\mathrm{n}=262)\end{array}$ \\
\hline Not goal throw & $\begin{array}{c}22,11 \pm 4,28^{*} \\
(\mathrm{n}=238)\end{array}$ & $\begin{array}{c}23,84 \pm 3,94 \\
(\mathrm{n}=669)\end{array}$ & $\begin{array}{c}21,59 \pm 4,05^{*} \\
(\mathrm{n}=249)\end{array}$ \\
\hline
\end{tabular}

Legend: Significant differences between field zones $(\mathrm{p} \leq 0.000):(*)$ with centre.

In Table 1, we can observe the analysis of the all the throws registered in the world championship from the lateral and central zones of the attacking field. As it can be observed, we find that the greatest speeds are reached from the central zone. These differences reached statistical significance when comparing the rightlateral zone with the central zone $(p<0.00)$, and the left-lateral zone with the central zone $(p<0.00)$ both in goal throws and non-goal throws. However, there were not significant differences between the speeds reached in the left and right laterals (Table 1). When analyzing the speed between the first eight and the 
second eight classified teams, significant differences were not found in the throwing speed, regardless of its efficacy, in the left-lateral zone of the attacking field (Table 2).

Table 2. Mean and standard deviations values ( $\bar{x} \pm s d$ ) corresponding to throwing velocity from the left side of the field between the top 8 finishers and the 8 second finishers.

\begin{tabular}{|l|c|c|c|}
\hline Area A & $\begin{array}{c}\text { Top 8 National Teams } \\
\left(\mathbf{m}^{*} \mathbf{s}^{-1}\right)\end{array}$ & $\begin{array}{c}\text { Second 8 National Teams } \\
\left(\mathbf{m}^{*} \mathbf{s}^{-1}\right)\end{array}$ & $\mathbf{p}$ \\
\hline All throws & $\begin{array}{c}22,78 \pm 4,20 \\
(\mathrm{n}=275)\end{array}$ & $\begin{array}{c}22,75 \pm 4,26 \\
(\mathrm{n}=94)\end{array}$ & 0,735 \\
\hline Goal throw & $\begin{array}{c}23,11 \pm 4,31 \\
(\mathrm{n}=137)\end{array}$ & $\begin{array}{c}23,40 \pm 3,79 \\
(\mathrm{n}=47)\end{array}$ & 0,853 \\
\hline Not Goal throw & $\begin{array}{c}22,46 \pm 4,20 \\
(\mathrm{n}=138)\end{array}$ & $\begin{array}{c}22,09 \pm 4,07 \\
(\mathrm{n}=47)\end{array}$ & 0,514 \\
\hline
\end{tabular}

In Table 3 we can observe the analysis of the throwing speed in the central zone of the field between the first eight and second eight classified teams. The first eight teams carried out the throws at a greater speed than the second eight teams in the throws performed in the central area of the attacking field $(p<0.001)$. Likewise, the first eight classified teams carried out the throws at a greater speed in the goal throws $(p<0.05)$ as well as in the non-goal throws $(p<0.05)$ than the second 8 classified teams.

Table 3. Mean and standard deviations values $(\bar{x} \pm s d$ ) corresponding to throwing velocity from the centre of the field between the top 8 finishers and the 8 second finishers.

\begin{tabular}{|l|c|c|c|}
\hline Area B & $\begin{array}{c}\text { Top 8 National Teams } \\
\left(\mathbf{m}^{*} \mathbf{s}^{-1}\right)\end{array}$ & $\begin{array}{c}\text { Second 8 National Teams } \\
\left(\mathbf{m}^{*} \mathbf{s}^{-1}\right)\end{array}$ & $\mathbf{p}$ \\
\hline All throws & $\begin{array}{c}24,35 \pm 3,89 \\
(\mathrm{n}=690)\end{array}$ & $\begin{array}{c}23,60 \pm 3,58 \\
(\mathrm{n}=327)\end{array}$ & 0,000 \\
\hline Goal throw & $\begin{array}{c}24,36 \pm 3,64 \\
(\mathrm{n}=356)\end{array}$ & $\begin{array}{c}23,40 \pm 3,52 \\
(\mathrm{n}=156)\end{array}$ & 0,002 \\
\hline Not goal throw & $\begin{array}{c}24,35 \pm 4,15 \\
(\mathrm{n}=334)\end{array}$ & $\begin{array}{c}23,79 \pm 3,64 \\
(\mathrm{n}=171)\end{array}$ & 0,039 \\
\hline
\end{tabular}

Significant differences were not found in the throwing speed among the first eight and the second eight classified teams in the throws carried out in the right-lateral zone of the attacking field. As shown in Table 4, these differences in the throwing speed did not reach statistical significance neither in the throws that ended up in the goal nor in those that did not.

Table 4. Mean and standard deviations values $(\bar{x} \pm s d)$ corresponding to throwing velocity from right side of the field, between the top 8 finishers and the 8 second finishers.

\begin{tabular}{|l|c|c|c|}
\hline Area C & $\begin{array}{c}\text { Top 8 National Teams } \\
\left(\mathbf{m}^{*} \mathbf{s}^{-1}\right)\end{array}$ & $\begin{array}{c}\text { Second 8 National Teams } \\
\left(\mathbf{m}^{*} \mathbf{s}^{-1}\right)\end{array}$ & $\mathbf{p}$ \\
\hline All throws & $\begin{array}{c}22,31 \pm 4,11 \\
(\mathrm{n}=277)\end{array}$ & $\begin{array}{c}21,76 \pm 3,85 \\
(\mathrm{n}=125)\end{array}$ & 0,158 \\
\hline Goal throw & $\begin{array}{c}22,47 \pm 4,11 \\
(\mathrm{n}=152)\end{array}$ & $\begin{array}{c}21,95 \pm 3,75 \\
(\mathrm{n}=64)\end{array}$ & 0,321 \\
\hline Not goal throw & $\begin{array}{c}22,12 \pm 4,12 \\
(\mathrm{n}=125)\end{array}$ & $\begin{array}{c}21,56 \pm 3,98 \\
(\mathrm{n}=61)\end{array}$ & 0,317 \\
\hline
\end{tabular}




\section{DISCUSSION}

The main achievement of this study is to provide throwing speeds registered in real competition situations at maximum level. Up to now, the speed values published came from studies carried out either in controlled or in training situations. Likewise, it is obvious that the greater speeds are registered in the cen tral zone of the attacking field in real competition situations.

Out of the throws registered in the area corresponding to the offensive first line (left-back, centre-back and right-back), the greater number of throws (56.8\%) and the greater speeds have been carried out from the central zone, being statistically significative with respect to the speeds registered in the lateral zones, no matter whether they ended up inside the goal or not. In handball, the greater number of defenders is found in the central zone, for this reason the throws are normally carried out with a defender near, and at a greater distance (9-8 metres). This situation makes the player to carry out a throw at a greater speed in order to reach a positive action (goal). Several authors, (Bayios et al., 1998; Van Den Tillaar \& Ettema, 2004; Van den Tillaar \& Ettema, 2007; Van den Tillaar \& Ettema, 2003), consider that the throw success is influenced by its precision and the ball speed; this coincides with the results of our study, where the greatest speeds are obtained when the throws end up inside the goal. In the literature for this field some sources speak about the existing inverse relation between velocity and precision, but Van de Tillar \& Ettemaa (2003), suggest that precision at maximum speed is already trained with highly experienced players. Only a few studies investigate throwing speed with opposition (Rivilla et al., 2011a; Rivilla et al., 2010b; Rivilla et al., 2011b), where a negative relation between the degree of opposition and throwing speed is found; in these studies, it is suggested that the cognitive workload has a negative influence on speed, but this does not occur in the results of this study, that is why it is necessary to analyse the specific behaviours of speed during the competition.

When the speeds related to the first and the last eight classified teams are analysed, the differences can only be observed in the centre zone; for this reason, it is necessary to deal with studies from an ecological perspective to verify these results, since the explanation does not seem to be based on the results of studies carried out in laboratory situations. Considering the speeds registered, we can establish some reference ranges concerning the speeds that the best teams perform in competition situations. For zone $A$, the identified speed ranges fluctuate between $22,1-23,1 \mathrm{~m} / \mathrm{s}^{-1}$; for zone $C$, between $21,5-22,5 \mathrm{~m} / \mathrm{s}^{-1}$; and for zone $B$, between $23,4-24,4 \mathrm{~m} / \mathrm{s}^{-1}$.

Considering that data obtained in competition have been used for this study, it is not appropriate to compare them with those obtained in controlled or training situations. However, overcoming these differences in data collection, it should be noted that the data published about throwing speed during the training session do not seem to differ much from those presented in this study $\left(23,4-24,4 \mathrm{~m} / \mathrm{s}^{-1}\right)$. The speed ranges in our study are similar to those presented by Prokajack (1980) with players from the Australian national team $\left(22.2 \mathrm{~m} . \mathrm{s}^{-1}\right)$, or to those by Gorostiaga et al. (2005) with professional players $\left(23.8 \mathrm{~m}^{-1}\right)$. However, they seem to be slightly lower if compared to the study by Rivilla et al. (2011b) who assessed a sample of ASOBAL players (28.11 m. $\mathrm{s}^{-1}$ ), or to study by Bayios et al. (1998) who analysed the throwing speed of first division Greek players $\left(26.27 \mathrm{m.s}^{-1}\right)$. The disparity of these results is probably due to the aforementioned comments since, in controlled situations, the type of throw, the opposition and the motivation are not the same as the ones in real competition situations. 


\section{CONCLUSIONS}

The best teams obtain higher throwing speed in the central position, but there is no difference in relation to effectiveness. Players may increase the throwing speed in the central position due to the concentration of a higher number of players in that area.

The experiments comply with the current laws of Spain.

\section{REFERENCES}

1. Aguilar-Martínez, D., Chirosa, L. J., Martín, I., Chirosa, I. J., \& Cuadrado-Reyes, J. (2012). Efecto del entrenamiento de la potencia sobre la velocidad de lanzamiento en balonmano. Revista Internacional De Medicina Y Ciencias De La Actividad Física Y Del Deporte, (48), 9-9.

2. Bárcenas, D., \& Román, J. D. (1991). Balonmano. técnica y metodología. Madrid: GYMNOS.

3. Bayios, I., Georgiadis, G., \& Boudolos, K. (1998). Accuracy and throwing velocity in handball. Proceedings of the XVIth International Symposium on Biomechanics in Sports, Konstanz - Germany, 1(1)

4. Cohen, J. (1960). A coefficient of agreement for nominal scales. Educational and Psychosocial Measurement, 20, 37-46. https://doi.org/10.1177/001316446002000104

5. Debanne, T., \& Laffaye, G. (2011). Predicting the throwing velocity of the ball in handball with anthropometric variables and isotonic tests. Journal of Sports Sciences, 29(7), 705-713. https://doi.org/10.1080/02640414.2011.552112

6. Gabín, B. (2011). Lince, automatización de datos observacionales para "Avances tecnológicos y metodológicos en la automatización de estudios observacionales en deporte". Unpublished manuscript.

7. García, J. A., Sabido, R., Barbado, D., \& Moreno, F. J. (2013). Analysis of the relation between throwing speed and throwing accuracy in team-handball according to instruction. European Journal of Sport Science, 13(2), 149-154. https://doi.org/10.1080/17461391.2011.606835

8. Gómez, J. S., Sabido, R., Gómez-Valadés, J. M., \& Barbado, F. D. (2011). Influencia aguda de la aplicación de un tratamiento de fuerza basado en el método de contrastes combinado, sobre la precisión y la velocidad del lanzamiento en balonmano. E-Balonmano.Com: Revista De Ciencias Del Deporte, 7(1), 5-16.

9. Gorostiaga, E. M., Granados, C., Ibanez, J., \& Izquierdo, M. (2005). Differences in physical fitness and throwing velocity among elite and amateur male handball players. International Journal of Sports Medicine, 26(03), 225-232. https://doi.org/10.1055/s-2004-820974

10. Gorostiaga, E. M., Izquierdo, M., Iturralde, P., Ruesta, M., \& Ibá-ez, J. (1999). Effects of heavy resistance training on maximal and explosive force production, endurance and serum hormones in adolescent handball players. European Journal of Applied Physiology and Occupational Physiology, 80(5), 485-493. https://doi.org/10.1007/s004210050622

11. Granados, C., Izquierdo, M., Ibá-ez, J., Ruesta, M., \& Gorostiaga, E. M. (2013). Are there any differences in physical fitness and throwing velocity between national and international elite female handball players? Journal of Strength and Conditioning Research / National Strength \& Conditioning Association, 27(3), 723-732.

12. Hermassi, S., van den Tillaar, R., Khlifa, R., Chelly, M. S., \& Chamari, K. (2015). Comparison of inseason-specific resistance vs. A regular throwing training program on throwing velocity, anthropometry, and power performance in elite handball players. Journal of Strength and 
Conditioning Research / National Strength \& Conditioning Association, 29(8), 2105-2114. https://doi.org/10.1519/JSC.0000000000000855

13. Landis, J. R., \& Koch, G. G. (1977). The measurement of observer agreement for categorical data. Biometrics, 33(1), 159-174. https://doi.org/10.2307/2529310

14. Lozano, D. (2014). Análisis del comportamiento táctico ofensivo en alto rendimiento en balonmano. Universitat de Lleida).

15. Prokajac, B. (1980). Difference between initial ball velocites when using a sidearm throw in fieldball. Revista Física Cultura, 34, 333-337.

16. Raeder, C., Fernandez-Fernandez, J., \& Ferrauti, A. (2015). Effects of six weeks of medicine ball training on throwing velocity, throwing precision, and isokinetic strength of shoulder rotators in female handball players. Journal of Strength and Conditioning Research / National Strength \& Conditioning Association, 29(7), 1904-1914. https://doi.org/10.1519/JSC.0000000000000847

17. Rivilla, J., Martínez, I., Grande, I., \& Sampedro, J. (2011a). Relation between general throwing tests with a medicine ball and specific tests to evaluate throwing velocity with and without opposition in handball. Journal of Human Sport \& Exercise, 6(2), 414-426. https://doi.org/10.4100/ihse.2011.62.22

18. Rivilla, J., Sampedro, J., Navarro, F., \& Gómez, M. (2010a). Influence of the opposition in throwing velocity in elite, amateur and formative handball players. Int J Sport Sci, 18(6), 91-99.

19. Rivilla, J., Grande, I., Sampedro, J., \& Van den Tillaar, R. (2011b). Influence of opposition on ball velocity in the handball jump throw. Journal of Sports Science and Medicine, 10(3), 534-539.

20. Rivilla, J., Martín, I. M., Valdivielso, F. N., \& Molinuevo, J. S. (2010b). Differences in the throwing distance and ball velocity by playing position in under-18 handball players. RICYDE. Revista Internacional De Ciencias Del Deporte., 7(22), 14-23. https://doi.org/10.5232/ricyde2011.02202

21. Rogulj, N., Srhoj, V., Nazor, M., Srhoj, L., \& Cavala, M. (2005). Some anthropologic characteristics of elite female handball players at different playing positions. Collegium Antropologicum, 29(2), 705709.

22. Sabido, R., Hernández-Davó, J. L., Botella, J., \& Moya, M. (2016). Effects of 4-week training intervention with unknown loads on power output performance and throwing velocity in junior team handball players. PloS One, 11(6), 1-12. https://doi.org/10.1371/journal.pone.0157648

23. Serrien, B., Clijsen, R., Anders, S., Goossens, M., \& Baeyens, J. (2016). Intra-seasonal variability of ball speed and coordination of two team-handball throwing techniques in elite male adolescent players. International Journal of Computer Science in Sport, 15(1), 1-21. https://doi.org/10.1515/ijcss-2016-0001

24. Van den Tillaar, R. (2004). Effect of different training programs on the velocity of overarm throwing: A brief review. Journal of Strength and Conditioning Research / National Strength \& Conditioning Association, 18(2), 388-396. https://doi.org/10.1519/00124278-200405000-00033

25. Van den Tillaar, R., Zondag, A., \& Cabri, J. (2013). Comparing performance and kinematics of throwing with a circular and whip-like wind up by experienced handball players. Scandinavian Journal of Medicine \& Science in Sports, 23(6), e373-e380. https://doi.org/10.1111/sms.12091

26. Van den Tillaar, R. (2003). Effect of different constraints on coordination and performance in overarm throwing. Fakultet for samfunnsvitenskap og teknologiledelse.

27. Van den Tillaar, R., \& Ettema, G. (2004). A force-velocity relationship and coordination patterns in overarm throwing. Journal of Sports Science and Medicine, 3(4), 211-219.

28. Van den Tillaar, R., \& Ettema, G. (2007). A three-dimensional analysis of overarm throwing in experienced handball players. Journal of Applied Biomechanics, 23(1), 12-19. https://doi.org/10.1123/jab.23.1.12 
29. Van den Tillaar, R., \& Marques, M. (2011). Effect of training on ball release velocity and kinematics in overarm throwing among experiencied female handball players. Kinesiologia Slovenica, 17(2), 3846.

30. Van den Tillaar, R., \& Ettema, G. (2003). Influence of instruction on velocity and accuracy of overarm throwing. Perceptual and Motor Skills, 96(2), 423-434. https://doi.org/10.2466/pms.2003.96.2.423

31. Van den Tillaar, R., \& Ettema, G. (2003). Instructions emphasizing velocity, accuracy, or both in performance and kinematics of overarm throwing by experienced team handball players. Perceptual and Motor Skills, 97(3 Pt 1), 731-742. https://doi.org/10.2466/pms.2003.97.3.731

32. Vila, H., Alcaraz, P., Ferragut, C., Rodríguez, N., \& Cruz, M. (2009). Perfil cineantropométrico, composición corporal y condición física en jugadoras de balonmano de nivel nacional. Apunts : Educación Física Y Deportes, (98), 46; 46-50; 50.

33. Wagner, H., Buchecker, M., von Duvillard, S. P., \& Müller, E. (2010). Kinematic description of elite vs. low level players in team-handball jump throw. Journal of Sports Science and Medicine, 9, 1523.

34. Wagner, H., Pfusterschmied, J., Duvillard, S. P., \& Müller, E. (2011). Performance and kinematics of various throwing techniques in team-handball. Journal of Sports Science \& Medicine, 10(1), 73-80.

35. Wagner, H., Pfusterschmied, J., Tilp, M., Landlinger, J., Von Duvillard, S., \& Müller, E. (2014). Upperbody kinematics in team-handball throw, tennis serve, and volleyball spike. Scandinavian Journal of Medicine \& Science in Sports, 24(2), 345-354. https://doi.org/10.1111/j.1600-0838.2012.01503.x

36. Zapartidis, I., Toganidis, T., Vareltzis, I., Christodoulidis, T., Kororos, P., \& Skoufas, D. (2009). Profile of young female handball players by playing position. Serbian Journal of Sports Sciences, 3(2), 5360. 